\title{
Craniometrical characteristics of Neomys fodiens (Pennant, 1771) (Mammalia, Insectivora) from the northeastern Iberian Peninsula
}

\author{
Ma José LÓPEZ-FUSTER, Jacinto VENTURA, \\ Marta MIRALLES and Enrique CASTIÉN
}

\begin{abstract}
López-Fuster M. J., Ventura J., Miralles M. and Castién E. 1990. Craniometrical characteristics of Neomys fodiens (Pennant, 1771) (Mammalia, Insectivora) from the northeastern Iberian Peninsula. Acta theriol. 35: 269-276.
\end{abstract}

The aim of this paper was to establish the craniometrical features of Neomys fodiens (Pennant, 1771) from the northeastern Iberian Peninsula (Catalonia). The variability in 22 skull and mandible measurements in a series of forty eight specimens was studied. Fifty seven specimens from Navarre were used for comparison. The specimens from Catalonia display smaller skull sizes than those from Navarre ( $N$. f. niethammeri) and should be assigned to the nominal subspecies, $N$. $f$. fodiens. The greatest differences between both samples are observed in dental measurements and for the rostral region. A discriminant function was established. The variables selected according to their discriminant power were $\mathrm{HC}$ and PGW. This function enables us to obtain a $94.4 \%$ correct discrimination between both samples. The differentiation in $N$. fodiens in the Iberian Peninsula is discussed and attributed to historical and ecological factors.

Departamento de Biología Animal (Vertebrados), Facultad de Biología, Universidad de Barcelona, Avda. Diagonal 645, 08028 Barcelona, Spain (MJL-F, JV, MM); Departamento de Ciencias Morfológicas, Facultad de Medicina, Universidad de Barcelona, Avda. Diagonal s/n, 08028 Barcelona, Spain (JV); Sociedad de Ciencias Aranzadi, Sección Vertebrados, Plaza Ignacio Zuloaga s/n, San Sebastián, Spain (EC)

Key words: craniometry, Neomys fodiens, Iberian Peninsula

\section{Introduction}

Despite Miller's mention (1912) of the possible presence of Neomys fodiens in the Iberian Peninsula, the first precise reference to the species belongs to Cabrera (1914), who mentions it in the Pyrenees of Huesca. According to Ellerman and Morrison-Scott (1951), the Iberian individuals correspond to the nominal subspecies, $N$. $f$. fodiens (Pennant, 1771).

Later on, Bühler (1963) describes a new subspecies, $N$. $f$. niethammeri, (Terra Typica: Ramales de la Victoria, Santander), characterised by its larger skull size towards N. f. fodiens. Heim de Balsac and de Beaufort (1969), Vericad (1970) and Pemán (1983) refer the individuals from the Picos de Europa, Navarre and the Basque Country, respectively, to this subspecies. However, Nores et al. (1982) argued about the subspecific validity of $N$. $f$. niethammeri.

Other studies have reported certain features about the distribution and morphology of $N$. fodiens in the Iberian Peninsula (Sánchez-Canals 1977, Nores 1979). Data 
on the populations from the northeast of this area are limited to those provided by Sans-Coma and Margalef (1981), based on two specimens.

In this paper the craniometrical characteristics of $N$. fodiens from Catalonia are given, to determine its taxonomical status and provide more in-depth knowledge of this species in Spain.

\section{Material and methods}

Forty eight individuals ( 23 males, 22 females, 3 ?) from the northeastern Iberian Peninsula (Catalonia) were analysed. They were captured in the following locations (U.T.M. $10 \times 10 \mathrm{~km}$ ): Lérida: Bausén (31TCH14), Bossost (31TCH13), Les Bordes (31TCH13), Aubert (31TCH13), Viella (31TCH13), Salardú (31TCH23); Girona: Espinavell (31TDG59), Setcases (31TDG49). Fifty seven individuals (28 males, 29 females) from Quinto Real (30TXN26), Navarre, were used for comparison.

The following 22 measurements were taken (Fig. 1): CIL: condyle-incisor length; CBL: condyle-basal length; RL: rostral length; SCL: skull case length; SBL: staphylion-basion length; USDi: length of the upper dental series; USD: length of the upper dental series without incisor; $\mathrm{P}^{4} \mathrm{M}^{3}: \mathrm{P}^{4} \mathrm{M}^{3}$ length; $\mathrm{OW}$ : infraorbital width; IOW: interorbital width; ZW: zygomatic width; PGW: postglenoid width; SCW: skull case width; $\mathrm{SCH}$ : skull case height; IAL: incisor-angle length; ANL: angular length; ARL: articular length; $\mathrm{CL}$ : coronoid length; $\mathrm{CH}$ : coronoid height; $\mathrm{LDSi}$ : length of the lower dental series; $\mathrm{CM}_{3}: \mathrm{CM}_{3}$ length; $\mathrm{M}_{1} \mathbf{M}_{3}: \mathbf{M}_{1} \mathbf{M}_{3}$ length.

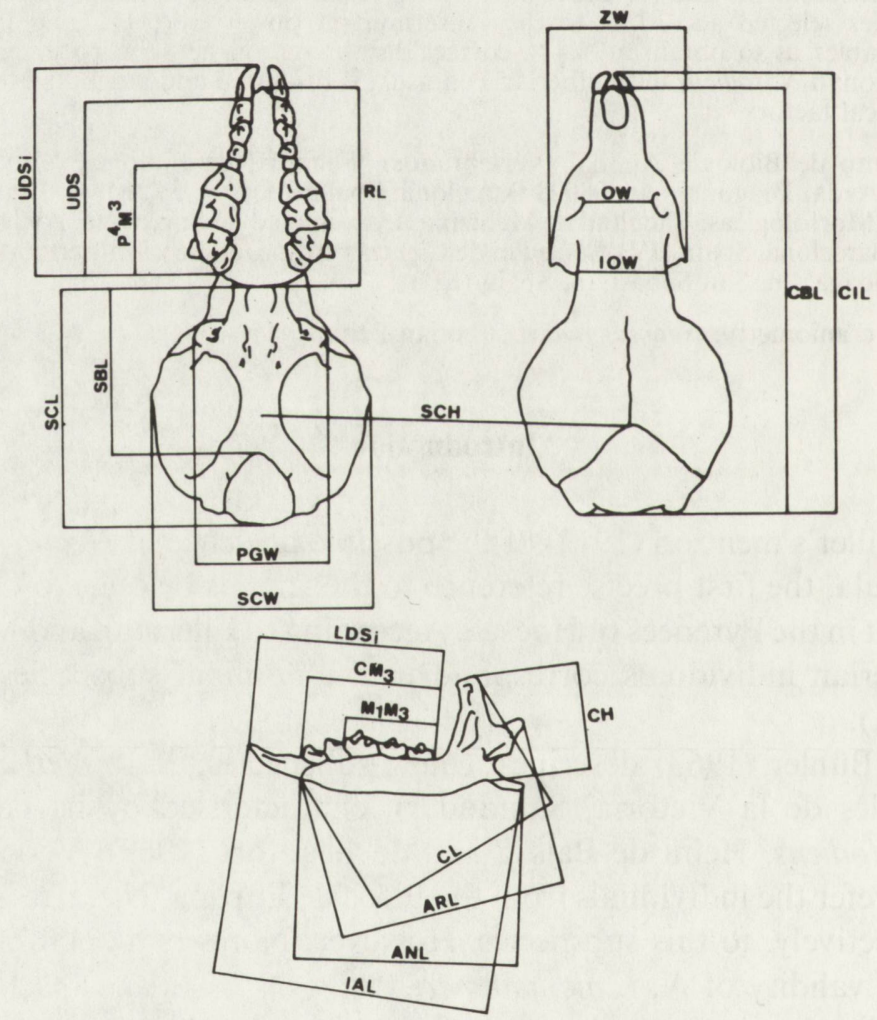

Fig. 1. Cranial and mandibular parameters measured in Neomys fodiens. 
The specific identification of the individuals was carried out from the morphological characteristics of the mandible and the discriminant formula established by Bühler (1964).

For the statistical analysis, the normality of variables and homogeneity of variances was presumed. The differences between sample mean values were evaluated using $d$ and $t$ Student statistics (Parker 1976, Sokal and Rohlf 1979). Discriminant-function analysis was used to define similarities or dissimilarities between samples (Jennrich and Sampson, 1983). The data were processed on an IBM 3083/XE01 computer in the University of Barcelona Computer Centre.

\section{Results}

The specimens from Catalonia display smaller skull and mandible sizes than those from Navarre (Table 1). Statistical comparison of the sample means points to significant differences in all the parameters analysed, except for SCL, SBL and SCW. The significance level for all variables was $p<0.001$, except for SCH $(p<0.02)$. The differences in total skull length are mainly due to the elongation of the rostral region in the individuals from Navarre.

To complete these observations, a discriminant function was established sequentially (Jennrich and Sampson 1983), using all the parameters analysed. The variables selected according to their discriminant power were $\mathrm{CH}$ and PGW. Subsequently, the individuals were classified for each population group (Catalonia, Navarre) according to the canonical coefficient of each variable. The results obtained are as follows:

\begin{tabular}{lccc}
\hline Group & $\begin{array}{c}\text { Correct } \\
\text { percentage }\end{array}$ & $\begin{array}{c}\text { Catalonia } \\
\text { group }\end{array}$ & $\begin{array}{c}\text { Navarre } \\
\text { group }\end{array}$ \\
\hline Catalonia & 91.7 & 33 & 3 \\
Navarre & 96.2 & 2 & 51 \\
Total & 94.4 & 35 & 54 \\
\hline
\end{tabular}

As can be seen, the total percentage of discrimination is $94.4 \%$. The distribution of individuals from each group on the canonical axis is represented in Fig. 2, using only those specimens with complete skull and mandible measurements. The discriminant function is: $d=-2.71951 \mathrm{PGW}-4.33769 \mathrm{CH}+40.20525$.

The discrimination criterion is geometrical: the canonical coordinates have been taken from individual averages for each group (Navarre: $\mathrm{k}_{1}=-0.94747$; Catalonia:

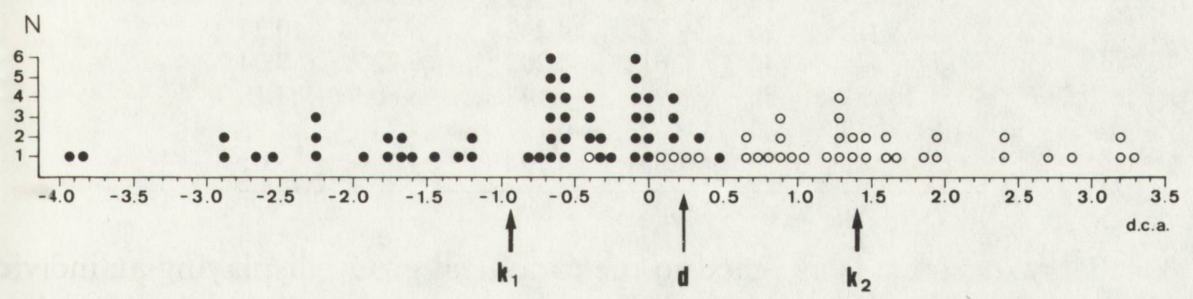

Fig. 2. Distribution of the specimens of Neomys fodiens from Navarre $(\mathbf{)})$ and Catalonia $(\mathrm{O})$ in the discriminant canonical axis (d. c. a.). The discriminant function is: $d=-2.71951 \mathrm{PGW}-4.33769 \mathrm{CH}$ $+40.20525 . \mathrm{k}_{1}, \mathrm{k}_{2}$ : canonical variables evaluated over the averages of each group; $d=\mathrm{k}_{1}+\mathrm{k}_{2} / 2$. 
Table 1. Measurements (in $\mathrm{mm}$ ) of Neomys fodiens from Catalonia (C) and Navarre (N).

\begin{tabular}{|c|c|c|c|c|c|c|}
\hline Variable & & $\mathrm{n}$ & $\bar{x}$ & SD & $\min$ & $\max$ \\
\hline \multirow[t]{2}{*}{ CIL } & C & 22 & 21.850 & 0.645 & 20.00 & 22.84 \\
\hline & $\mathrm{N}$ & 55 & 22.525 & 0.411 & 21.67 & 23.32 \\
\hline \multirow[t]{2}{*}{ CBL } & C & 22 & 21.007 & 0.554 & 19.61 & 22.03 \\
\hline & $\mathrm{N}$ & 55 & 21.505 & 0.475 & 20.47 & 22.51 \\
\hline \multirow[t]{2}{*}{ RL } & $\mathrm{C}$ & 39 & 10.225 & 0.422 & 9.24 & 10.91 \\
\hline & $\mathrm{N}$ & 55 & 10.643 & 0.278 & 9.65 & 11.37 \\
\hline \multirow[t]{2}{*}{ SCL } & C & 23 & 10.907 & 0.458 & 9.82 & 11.82 \\
\hline & $\mathrm{N}$ & 56 & 11.092 & 0.227 & 10.54 & 11.54 \\
\hline \multirow[t]{2}{*}{ SBL } & C & 19 & 8.661 & 0.267 & 8.16 & 9.05 \\
\hline & $\mathrm{N}$ & 56 & 8.691 & 0.221 & 8.06 & 9.09 \\
\hline \multirow[t]{2}{*}{ USDi } & C & 38 & 10.234 & 0.337 & 9.46 & 10.94 \\
\hline & $\mathrm{N}$ & 54 & 10.709 & 0.200 & 10.26 & 11.19 \\
\hline \multirow[t]{2}{*}{ USD } & C & 38 & 8.647 & 0.272 & 8.15 & 9.28 \\
\hline & $\mathrm{N}$ & 55 & 9.033 & 0.192 & 8.40 & 9.41 \\
\hline \multirow[t]{2}{*}{$\mathrm{P}^{4} \mathbf{M}^{3}$} & $\mathrm{C}$ & 38 & 5.608 & 0.119 & 5.26 & 5.94 \\
\hline & $\mathrm{N}$ & 57 & 5.916 & 0.122 & 5.64 & 6.19 \\
\hline \multirow[t]{2}{*}{ OW } & C & 39 & 3.342 & 0.109 & 3.10 & 3.59 \\
\hline & $\mathrm{N}$ & 55 & 3.483 & 0.133 & 3.13 & 3.86 \\
\hline \multirow[t]{2}{*}{ IOW } & C & 37 & 4.540 & 0.097 & 4.30 & 4.73 \\
\hline & $\mathrm{N}$ & 55 & 4.674 & 0.163 & 4.34 & 5.11 \\
\hline \multirow[t]{2}{*}{ ZW } & C & 38 & 6.757 & 0.246 & 6.30 & 7.34 \\
\hline & $\mathrm{N}$ & 56 & 7.003 & 0.237 & 6.42 & 7.50 \\
\hline \multirow[t]{2}{*}{ PGW } & C & 37 & 6.246 & 0.171 & 5.78 & 6.57 \\
\hline & $\mathrm{N}$ & 55 & 6.553 & 0.163 & 6.16 & 7.03 \\
\hline \multirow[t]{2}{*}{ SCW } & C & 22 & 10.820 & 0.194 & 10.52 & 11.13 \\
\hline & $\mathrm{N}$ & 56 & 10.863 & 0.247 & 10.21 & 11.30 \\
\hline \multirow[t]{2}{*}{$\mathrm{SCH}$} & C & 29 & 5.675 & 0.207 & 5.23 & 6.17 \\
\hline & $\mathrm{N}$ & 56 & 5.772 & 0.161 & 5.41 & 6.19 \\
\hline \multirow[t]{2}{*}{ IAL } & C & 39 & 14.045 & 0.452 & 13.07 & 14.98 \\
\hline & $\mathrm{N}$ & 55 & 14.514 & 0.319 & 13.58 & 15.13 \\
\hline \multirow[t]{2}{*}{ ANL } & C & 39 & 11.232 & 0.342 & 10.63 & 11.84 \\
\hline & $\mathrm{N}$ & 56 & 11.555 & 0.300 & 10.61 & 12.18 \\
\hline \multirow[t]{2}{*}{ ARL } & C & 40 & 11.432 & 0.319 & 10.85 & 11.96 \\
\hline & $\mathrm{N}$ & 55 & 11.869 & 0.284 & 11.11 & 12.49 \\
\hline \multirow[t]{2}{*}{ CL } & C & 40 & 9.910 & 0.342 & 9.19 & 10.59 \\
\hline & $\mathrm{N}$ & 56 & 10.457 & 0.332 & 9.76 & 11.22 \\
\hline \multirow[t]{2}{*}{$\mathrm{CH}$} & C & 40 & 5.056 & 0.163 & 4.73 & 5.48 \\
\hline & $\mathrm{N}$ & 56 & 5.388 & 0.172 & 5.10 & 5.89 \\
\hline \multirow[t]{2}{*}{ LDSi } & C & 40 & 9.396 & 0.323 & 8.74 & 10.02 \\
\hline & $\mathrm{N}$ & 55 & 9.775 & 0.242 & 8.73 & 10.24 \\
\hline \multirow[t]{2}{*}{$\mathrm{CM}_{3}$} & C & 40 & 6.617 & 0.202 & 6.22 & 7.04 \\
\hline & $\mathrm{N}$ & 56 & 6.902 & 0.142 & 6.60 & 7.18 \\
\hline \multirow[t]{2}{*}{$\mathrm{M}_{1} \mathrm{M}_{3}$} & C & 40 & 4.623 & 0.137 & 4.34 & 4.93 \\
\hline & $\mathrm{N}$ & 56 & 4.831 & 0.102 & 4.60 & 5.01 \\
\hline
\end{tabular}

$\mathrm{k}_{2}=1.39488$ ). A specimen is assigned to the canonical group displaying an individual value closer to the mean value for the group. Because the canonical variable is adjusted so that variances among the groups are equal, when the function is evaluated for the inclusion of a new individual, if $d>0.223\left[\left(\mathrm{k}_{1}+\mathrm{k}_{2}\right) / 2\right]$ it will be considered to belong to 
the group from Catalonia and if $d<0.223$, then it will be assigned to the group from Navarre.

The function obtained was applied to the individual measurements of the specimens from the Basque Country studied by Pemán (1983) $(n=57)$. Except for two cases, these individuals display values of $d$ included in the group from Navarre $(\mathrm{n}=55$, $96.49 \%)$, showing a mean value $(k)$ of -1.18824 .

\section{Discussion}

The results obtained agree with the morphometrical variation observed in $N$. fodiens in the Iberian Peninsula (Sánchez-Canals 1977, Nores 1979, Nores et al. 1982, Pemán 1983).

According to bibliographical data (Miller 1912, Cabrera 1914, Buchalczyk and Raczyński 1961, Bühler 1963, Pieper 1966, Rempe and Bühler 1966, Saint-Girons, 1973), the individuals from Catalonia should be assigned to the nominal subspecies, $N$. $f$. fodiens, whereas the specimens from Navarre fit the range values for $N$. f. niethammeri. These results corroborate the existence of at least two morphotypes of $N$. fodiens in the Iberian Peninsula. One morphotype is distributed in Navarre, the Basque Country and Eastern Asturias and has been considered N. f. niethammeri. The other morphotype, with smaller skull sizes, offers a scattered distribution, occupying the northern extremes of the Peninsula (Galicia-Western Asturias and Eastern Pyrenees) (Fig. 3). According to data in the literature, these latter individuals should be assigned to the nominal subspecies, $N$.f.fodiens. Nevertheless, this subspecific differentiation could be questioned.

If the craniometrical and morphological characteristics are considered, the
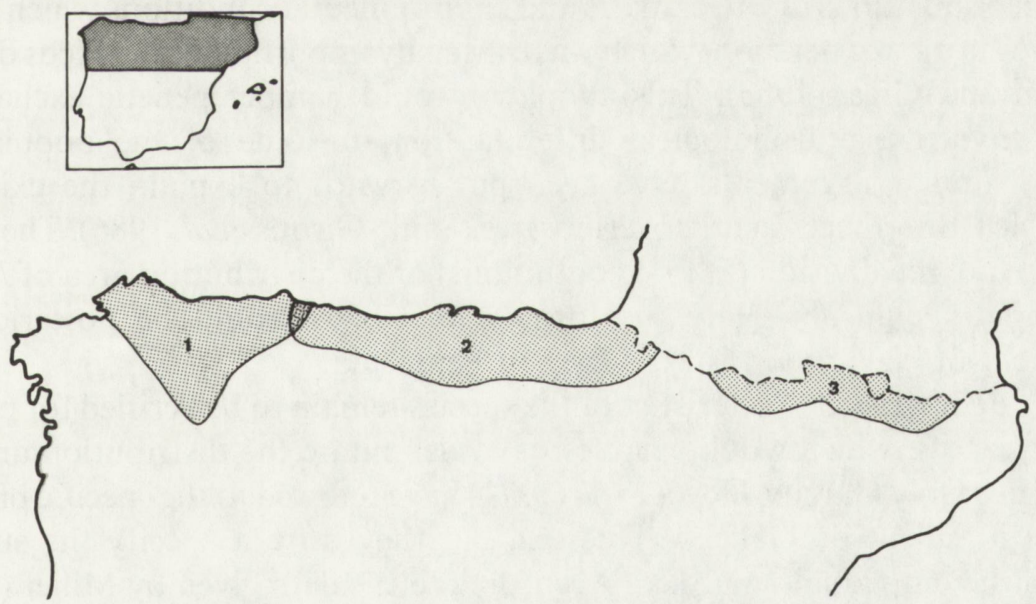

Fig. 3. Geographical distribution of Neomys fodiens in the Iberian Peninsula. 1, 3: N. f. fodiens; 2: N. $f$. niethammeri. Data from Vericad (1970), Sans-Coma and Margalef (1981), Nores et al. (1982), Pemán (1983), Gosálbez et al. (1985), González and Román (1988) and own data. 
separation of these forms into two subspecific categories seems to be correct. The existence of a cline, as Nores et al. (1982) point out, does not seem clear. The results obtained, together with the bibliographical data, show that the size differences in the species do not fit a geoclinal variation. In general, a gradual size variation is not observed from one end of the Iberian distribution area of the species to the other. The individuals of $N$.f. niethammeri, which are larger, occupy an intermediate geographical position between the occidental (Galicia-Western Asturias) and the oriental (Catalonia) populations, both attributed to $N$. f. fodiens (Fig. 3). Nevertheless, according to Nores et al. (1982), the areas of niethammeri and fodiens overlap in Asturias (Fig.3), although these authors do not describe the intergrade zone. This overlap is not in agreement with the definition for subspecies given by Mayr (1969) and therefore the taxonomical status of the species in this area remains to be solved.

The larger skull sizes of niethammmeri could be a result of a subspeciation process. As Thorpe (1987) points out this process can be motivated, in general, by ecological and historical factors. As regards the former, Nores et al. (1982) mention that the area occupied by $N$. f. niethammeri has a calcareous substrate. Therefore, because rivers with these characteristics are richer in nutrients, individuals with a more developed masticator apparatus could have been selected, as they would be in a better position to capture larger prey. In this sense, the greatest differences (larger $d$ or $t$ statistical values) between $N$. $f$. fodiens and $N$. f. niethammeri correspond to parameters connected with mastication (UDSi, UDS, $\mathrm{P}^{4} \mathrm{M}^{3}$, ARL, LDSi, $\mathrm{M}_{1} \mathrm{M}_{3}$ ).

Because $N$. fodiens is a species which is strictly linked with aquatic environments, the genetic flux between populations may be reduced, thus providing an opportunity for genetic drift and natural selection.

From a historical point of view, allopatry may have appeared among the Cantabrian populations due to climatic and environmental conditions which appeared during the Wurmian glaciation, which was especially important in the Picos de Europa (Nussbaum and Gigax 1953). This allopatry would hamper genetic exchange, and therefore, favour a morphological differentation in some of the populations of $N$. fodiens. Similar arguments have been put forward to explain the existence of morphological differences in other vertebrates (Saint-Girons et al. 1986). These factors would motivate the division (at first continuous) of the distribution area of $N$. fodiens in the Iberian Peninsula. Here the form niethammeri would be posterior to the establishment of $N$. $f$. fodiens in the Iberian Peninsula.

The existence and characteristics of the species remain to be verified for part of the Western Pyrenees, which would enables us to delimitate the distribution area of the Iberian forms. Only Garzón-Heydt et al.(1971) have referred to the specific presence of $N$. fodiens in Sallent de Gállego (Huesca), but they do not specify the subspecific category of the individuals analysed. According to the data given by Miller (1912) for the French Pyrenees, they may belong to the subspecies $N . f$. fodiens.

The possibility that the populations of niethammeri may represent a different species could be raised. From a biometrical and morphological point of view, 
differences between niethammeri and fodiens are more conspicuous than those between $N$. fodiens fodiens and $N$. anomalus (M. J. Lopez-Fuster, unpub.) Genetic, biochemical and ecological studies could establish the exact taxonomical status of $N$. fodiens populations in the Iberian Peninsula.

\section{References}

Buchalczyk T. S. and Raczyński J. 1961. Taxonomischer Wert einiger Schädelmessungen inländischer Vertreter der Gattung Sorex und Neomys. Acta theriol. 5: 115-124.

Bühler P. 1963. Neomys fodiens niethammeri ssp. n., eine neue Wasserspitzmausform aus Nord-Spanien. Bonn. zool. Beitr. 1/2: $165-170$.

Bühler P. 1964. Zur Gattungs- und Artbestimmung von Neomys- Schädeln. Z. Säugetierkunde 29: 65-93. Cabrera A. 1914. Fauna Ibérica. Mamíferos. Museo Nacional de Ciencias Naturales, Madrid: 1-441.

Ellerman J. R. and Morrison-Scott T. C. S. 1951. Checklist of the Palaearctic and Indian Mammals 1758 to 1946. British Museum (Nat. Hist.), London: 1-810.

Garzón-Heydt J., Castroviejo J. and Castroviejo S. 1971. Notas preliminares sobre la distribución de algunos micromamíferos en el Norte de España. Säugetierkdl. Mitt. 19: 217-222.

González J. and Román J. 1988. Atlas de Micromamíferos de la provincia de Burgos. Ed. Jorge González Esteban, Burgos: $1-154$.

Gosálbez J., López-Fuster M. J., Götzens G. and Sans-Coma V. 1985. El poblament dels petits mamífers (Insectivora, Rodentia) a Catalunya. Requeriments ambientals i distribució geográfica. Butll. Inst. Cat. Hist. Nat. 52: 209-230.

Heim de Balsac H. and de Beaufort F. 1968. Contribution à l'étude des micromammifères du Nord-Ouest de l'Espagne (Asturies, Santander, Galice, Leon). Mammalia 33: 630-658.

Jennrich R. and Sampson P. 1983. Stepwise discriminant analysis. [In: BMDP Statistical Software, W. J. Dixon, ed.]. Univ. of California Press, Berkeley, progr. 7m: 519-537.

Mayr E. 1969. Principles of Systematic Zoology. McGraw Hill, New York: 1-328.

Miller G. S. 1912. Catalogue of the Mammals of Western Europe. British Museum (Nat. Hist.), London: $1-1019$.

Niethammer J. 1964. Beitrag zur Kenntnis der Kleinsäuger Nordspaniens. Z. Säugetierkunde 29: 193-220.

Nores C. 1979. Nuevas aportaciones al conocimiento de la subfamilia Soricinae (Mammalia, Insectivora) en los distritos cantábrico y lusitano. Tesis de Licenciatura, Univ. de Oviedo.

Nores C., Sánchez-Canals J. L., Castro A. and González G. R. 1982. Variation du genre Neomys Kaup, 1829 (Mammalia, Insectivora) dans le secteur cantabro-galicien de la péninsule Ibérique. Mammalia 46: $361-373$.

Nussbaum F. and Gigax F.1953. La Glaciación cuaternaria en la Cordillera Cantábrica. Est. Geogr. 51: $261-270$.

Parker R. E. 1976. Estadística para Biólogos. Ed. Omega, Barcelona: 1-136.

Pemán E. 1983. Biometría y sistemática del género Neomys Kaup, 1771 (Mammalia, Insectivora) en el País Vasco. Munibe 35: 115-148.

Pieper H. 1966. Über die Artbestimmung von Neomys-Mandibeln mit Hilfe der Fischerschen Diskriminanz-Analyse. Z. Säugetierkunde 31: 402-403.

Rempe V. and Bühler P. 1969. Zum Einfluss der geographischen und alterbedingten Variabilität bei der Bestimmung von Neomys-Mandibeln mit Hilfe der Diskriminanz-Analyse. Z. Säugetierkunde 34: 148-164.

Saint-Girons H., Bea A. and Braña F. 1986. La distribución de los diferentes fenotipos de Vipera seoanei Lataste, 1879, en la región de los Picos de Europa (Norte de la Península Ibérica). Munibe 38: 121 - 128. 
Saint-Girons M. Ch. 1973. Les Mammifères de France et du Benelux (faune marine exceptée). Doin Ed., Paris: 1-481.

Sánchez-Canals J. L. 1977. Sobre la presencia del Musgaño patiblanco (Neomys fodiens) (Pennant, 1771) (Insectivora, Mammalia) en Galicia. Braña 1: 117-130.

Sans-Coma V. and Margalef R. 1981. Sobre los Isectívoros (Mammalia) del Pirineo catalán. Pirineos 113: $93-111$.

Sokal R. R. and Rohlf F. J. 1979. Biometría. Ed. Blume. Barcelona: 1-832.

Thorpe R. S. 1987. Geographic variation: a synthesis of case, data, pattern and congruence in relation to subspecies, multivariate analysis and phylogenesis. Boll. Zool. 54: 3-11.

Vericad J. R. 1970. Estudio faunístico y biológico de los mamfíferos montaraces del Pirineo. Pub. Centro Piren. Biol. Exp. 4. Jaca.

Received 30 March 1990, accepted 9 November 1990. 